\title{
"Tundang" Folk Songs of West Kalimantan Indonesia as Material of Local Wisdom Based Education
}

\author{
Adisti Primi Wulan ${ }^{1,2,{ }^{*}, \text { Maryaeni }^{1}, \text { Djoko Saryono }^{1} \text {, Taufik Dermawan }}{ }^{1}$ \\ ${ }^{1}$ Department of Indonesian Language Education, Postgraduate Program, Universitas Negeri Malang, Malang, Indonesia \\ ${ }^{2}$ Department of Language and Literature Education, IKIP PGRI Pontianak, Indonesia
}

Copyright $(2019$ by authors, all rights reserved. Authors agree that this article remains permanently open access under the terms of the Creative Commons Attribution License 4.0 International License

\begin{abstract}
This article describes the use, function and development of the folk songs of West Kalimantan, Tundang the supporting community by relating them to the cultural elements. Tundang, as one of the oral folklore in folk songs, can be used for learning in schools with cooperation between the teachers and the students. The preservation of the songs of the people of West Kalimantan can make changes to the preservation of other cultures by elevating them to a performance art that can be developed, namely increasing their coaching and expanding the area of its spread.
\end{abstract}

Keywords Folklore, Folk Songs, Tundang, Local Wisdom

\section{Introduction}

Folklore is an important element that exists in a system of cultural and social order of a society. Folklore is a social reflection of a society and all systems that are applied in it and a reflection of values both moral, ethical and normality values that are applied in a society. Besides that folklore can also be seen as a manifestation of the perspective (welthanschauung) of one society holistically, which means that a folklore that exists in a society can be seen as a projection of how a society thinks, acts, and behaves.

Folklore is one of the most important parts that cannot be separated from the course of human evolution up to now from various aspects, be it culture, social, philosophy, or religiosity $[1,2]$. Folklore is a universal phenomenon that can be found in every human culture that exists from time to time [3]. The age track record of folklore can be traced far back even far in the pre-literacy period. since ancient times humans have recorded stories of life and human perceptions of reality in a lore; before verbal communication abilities are formed as complex as today, humans tell stories through cave paintings; when verbal communication skills began to form perfectly, humans began to create verbal folklore [4]. Along with the development of culture, psychology, and human intelligence, folklore also developed in line with it, humans began to create rituals, beliefs, as a form of admiration for nature and life. Along with the emergence of spirituality and religiosity in human culture, art and cultural artifacts began to develop as humans began to recognize beauty or aesthetics. Folklore occupies an essential position in human life and has become an important part of human history, to this day.

Oral folklore is one form of Indonesian folklore which is an Indonesian cultural heritage that has been passed down from one generation to the next generation. Oral folklore plays an important role in the life of the community, nation, and state. Aside from being a characteristic of the Indonesian nation that distinguishes it from other nations, verbal folklore also has many functions as folklore in general. These functions include a projection system, an instrument for ratifying cultural institutions, as a means of enforcing and supervising community norms to be followed, and as an educational tool.

One of Oral folklore is the folk songs. Folk song of the people of West Kalimantan or commonly called tundang (pantun berdendang) is one of the local wisdom that until this time is still preserved. Tundang, as a result of human creativity, contains the values and ideas, dreams, philosophy, and collective consciousness of the people who create them, which are reflected both allegorically and literally; tundang expresses consciously or not how a community collective thinks, acts, behaves, and manifests a variety of mental attitudes, mindsets, values, and immortalize things that are considered important and developed in the form of a dubious rhyme.

Tundang as local wisdom can be used in learning at school as an education renewal in Indonesia, especially West Kalimantan, where currently education in all fields must be cultural in nature as one of the steps to preserve and promote Indonesian local wisdom. Something that becomes an obstacle in this local wisdom-based education is the spread of westernization in all levels of Indonesian 
society. This is due to the rapid progress of civilizations such as Information Technology (IT), the number of orientalism, occidentalism and so on.

\section{Methodology}

This research is included in literature review research. Literature review is a description about theories, findings, and other research material obtained from reference materials to be used as the research activities basis to develop a clear framework and problem formulation to be studied. In this research, researchers looked at the phenomena and potential in the research area, making the idea of potential development and utilization continued by search for supporting literature. The literature that is sought comes from books written by folklore and education experts.

\section{Result And Discussion}

Folklore comes from the words folk and lore. Folk has the same meaning with the word collective (collectivity). According to Alan Dundes, folk is a group that has physical, social, and cultural, so that it can be distinguished from other groups. Identifying features can be tangible:

a. Physical markers (skin color, hair style, etc.)

b. Social markers (livelihoods, education levels, activities)

c. Cultural markers (language, culture, activities, religion, etc.).

Lore is a folk tradition, that is, part of its culture, which is inherited from generation to generation orally or through an example accompanied by gestures or a tool to help reminders of mnemonic devices. Dundes states that folklore is very important for knowledge in humans' life because in it there are thoughts, words and actions that they do themselves. According to him, folklore is one proof of human existence and can be used to see self-reflection internally (psychologically) or externally (social and political), and rectify mistakes in the world, as he said as follows.

"Folklore is crucial to a knowledge of human experience, he observed, because as autobiographical ethnography," it permits a view "from the inside-out rather than from the outside-in." That is, the advantage of folklore is that it conveys what people think in their own words and actions, and what they say or sing in folklore expresses what they might not be able to in everyday conversation. Dundes argued that in folklore, more than in other forms of human evidence, "one finds a people's own unselfconscious picture of themselves" (xi). That picture is not always pretty, as Dundes exposed in studies of anti-Semitic folklore, ethnic slurs, and abusive initiations. He insisted that uncensored, untethered scholarship was necessary to get beyond the popular urge to romanticize lore. His cause was to confront the harsh realities in expressive traditions, toward the twin goals of knowing ourselves internally (that is, psychologically) and externally (or socially and politically), and of righting wrongs in the world" [5]

Endraswara [6] states that the distinctiveness of folklore lies in the aspect of its spread while Danandjaja [7] folklore are materials inherited from tradition, through words from mouth-mouth and from the practice of customs. In other words, folklore is basically a form of culture that is inherited and or inherited from generation to generation orally (orally).

Soeryawan [8] states that folklore is an art form that was born and spread among the masses. The characteristic of this cultural art which is an expression of distinctive human experience and appreciation is in its aesthetic-artistic form. Because in carrying out communicative relationships, art expresses it through the aesthetic forms he chooses.

From some of the definitions above, it can be concluded that folklore is a part of a collective culture, which is spread and passed down from generation to generation, among collective diversity, traditionally in different versions, both in oral and example forms accompanied by gestures or tools as reminder. The position of folklore with other cultures is different, because folklore has its own characteristics. According to Danandjaja [7], the main identifying characteristics of folklore can be formulated as follows.

a. Spread and inheritance are usually carried out verbally, which is spread by word of mouth.

b. Folklore is traditional, which is spread in a relatively fixed form or in a standard form.

c. Folklore exists (exist) in different versions and even variants. This is caused by the way it is spread from mouth to mouth (oral), usually not through printing or recording, so that by the process of forgetting humans or interpolation (interpolation).

d. Folklore is anonymous, namely the name of the creator is no longer known to people.

e. Folklore usually has a form of pattern, and always uses cliché words.

f. Folklore has uses as an educational tool, solace, social protest, and projection of pent-up desire.

g. Folklore is pralogical, which has its own logic which is not in accordance with general logic. This feature of recognition is especially true for oral and partially verbal folklore.

h. Folklore becomes a collective property of certain collectives. This is certainly due to the fact that the first creator is no longer known, so that each collective member concerned feels he owns it.

i. Folklore is generally innocent, so it often seems rude and too spontaneous. This is understandable when considering that folklore is the most honest projections of human emotions. 
The function of folklore, namely (1) as a projection system, namely as a reflection tool for the imagination of a collective, (2) as a means of ratifying cultural institutions and institutions, (3) as a child education tool, and (4) as a means of forcing and supervisors so that the norms of society will always be obeyed by their collective members. Jan Harold Brunvand, a United States folklorist, divides folklore into three major groups based on his type of oral, partially verbal, and not verbal folklore [7].

\subsection{Oral Folklor}

Oral Folklor is a folklore whose form is purely oral, and this type of folklore is also known as mental fact (mentifact). In the opinion of Rusyana [9] oral folklore or oral literature has the possibility to play a role as cultural wealth, especially the wealth of literature; as capital of literary appreciation because oral literature has guided community members towards appreciation and understanding of poetic ideas and events based on practices that have been a tradition for centuries; as the basis of communication between the creator and the community in the sense of creation based on oral literature. It will be easier to associate because there are elements that are already known to the public.

This type of folklore is known as mental fact (mentifact) which includes as follows:

a. People's language: language is used as a means of communication between people in a society or language that is used as a means of association in daily life, such as accent, dialect, vocabulary, and nickname, dialect, slang, taboo language, automatic

b. Traditional expressions: short sentence extracted from long experiences. Proverbs usually contain truth and wisdom like proverbs and satire

c. Traditional questions known as riddles. According to Alan Dundes, riddles are traditional oral expressions that contain one or more elements of painting, and the answer must be guessed. Although proverbs and riddles are small in comparison to people's pros stories and folk songs, an expert can spend his entire life researching both genres. According to Robert A. Georges and Aln Dundes, the riddle is "traditional oral expressions containing one or more elements of description (descriptive), a pair rather than being able to contradict each other and the answer (referent) must be guessed" (Dundes \& Bronner, 2007).

d. Folk poetry and poetry: people's literature which has a certain form usually occurs from several lines of sentence, some based on spells, some based on short lengths of syllables, weak sound pressure, or only based on rhythm [7]. In Sundanese folklore there are two forms of Sundanese poetry that can be said to be archaic are the forms of ajimantra and the form of poetry in the pantun story. The term ajimantra is taken from the ancient manuscript of the Karesian Penalty written in 1518 , meaning the term mantra now. While the poems in the pantun story are two, namely rajah and nataan. Rajah is a kind of salvation prayer from the pantun interpreter before and after telling the Sundanese pantun story. This form of rajah is just the same as the pantun story section called nataan.

e. Folk prose stories: is a story that is passed down from generation to generation (word of mouth) in the community. Folk prose stories can be divided into three major groups, namely myth, legend, and fairy tale (folktale).

f. Folk songs: an oral tradition from a society expressed through traditional songs or songs. Recreational function, which is to drive away the boredom of everyday life and to avoid the difficulties of life so that it can become a kind of solace, such as "Jali-Jali" from Betawi.

\subsection{Half-oral Folklore}

Half-oral folklore is a mixture of verbal and non-verbal elements. Usually, the form is not oral but the way of making it is taught orally. This folklore is also known as social fact (sociofact), including as follows:

a. Belief and superstition: this belief is often considered not based on logic because it cannot be scientifically accountable, concerning beliefs and practices. Inherited through the medium of speech.

b. Local people's games and entertainment: disseminated through oral traditions and widely distributed without the help of adults. Examples: arrogant, teplak, galasin, bekel, playing ropes, etc.

c. Folk theater, such as Lenong, Ketoprak, and Ludruk

d. Folk dance, such as tayuban, doger, jaran, kepang, and ngibing, ronggeng

e. Customs, such as salvation parties, and circumcision

f. Traditional ceremonies, the existence of religious beliefs or the beliefs of the local community. Traditional ceremonies are usually carried out as an expression of gratitude to the forces that are considered to provide protection and welfare to them, such as tingkeban, descending land, and meeting manten

g. Traditional folk parties such as village clean and meruwat.

\subsection{Non-oral Folklore}

These folklore are also known as artifacts, including the following:

a. Folk architecture: an art or science of designing buildings, such as traditional house buildings, inscriptions.

b. Traditional handicrafts

c. Traditional clothing: traditional clothes / jewelry that is typical of each region 
d. Folk medicine, for example herbal medicine from turmeric and ginger as a cold medicine

e. Traditional musical instruments

f. Typical traditional equipment and weapons

g. Typical foods and drinks.

\subsection{Oral Tradition and Folk Song}

Oral tradition, oral culture and oral custom are messages or testimonies that are verbally transmitted from one generation to next generation. Message or mandate was delivered in the form of speech, song and expressions contained in the form of pantun, folklore, advice, ballads, songs or proverbs. In this way a society can convey oral history and other knowledge to the subordinate generation as its successor without involving written language. Darson calls oral tradition (oral tradition) as folk literature (literature of the people).

Folk singing is one form of oral folklore consisting of rhythmic sounds and chords that are strung together to produce a beautiful harmonization. This is reinforced by Brudvand's statement in Danandjaja [7] that folk songs are a genre or form of folklore consisting of words and songs, circulating verbally among certain collective members, traditional in form, and many having variants. In folk songs words and songs are an inseparable whole. This is as Said [10] says that the poems sung both standing alone as songs or poems in stories, poems in incantations, or poems used in customs, which is called folk songs. However, the same text is not always sung with the same song. Conversely, the same song is often used to sing several different folk song texts. Folk songs are different from other songs, such as pop songs or classics. This is because the nature of folk songs is easy to change, both in form and in content. This non-rigid nature is not shared by other forms of singing.

Folk songs are more widely circulated to a community than other songs, because folk songs are circulating, both in literacy and illiterate circles, the upper class and the lower classes. Age of folk singing is longer than pop songs. The form of folk songs is also diverse, from the simplest to the most complicated. Its spread gave birth to oral traditions causing folk songs to tend to last very long and have a lot of variety. Folk songs have functions as solace, humorous songs, songs to accompany children's games, and songs "Nina Bobo". The second function is to generate enthusiasm, such as the "Holopis Kuntul Baris" chanting, singing for marching, struggle and so on. The third function is to preserve local history, and clen. The fourth function is as a social protest, regarding injustice in society, the state and even the world.

As one form of traditional art, folk songs are not known to be the creators because at the time the song was created a sense of togetherness is still far more important than individual interests. Folk songs include functional folk songs, lyrical folk songs, and storytelling folk songs. Functional folk songs are songs whose lyrics and songs match the rhythms of special activities in human life, for example kelonan songs like Nina Bobok; work songs such as Rambate Rata; or game songs such as baris terik tempe. Lullaby songs and play songs (playing song) belong to the class of folk songs that have functions in them. It is called functioning because both the lyrics and the song match the rhythms of special activities in human life. The song to put the child to sleep contains messages, advices, advice, hopes, ideals, and wishes of parents to their children from childhood to adulthood, while playing songs according to Danandjaja [7] are songs that have happy rhythms and funny words and always associated with play (game) or playing games (games, meanwhile, spiritual singing.

Lyrical folk songs are divided into two, namely the real and not real. Examples of real lyrical folk songs are songs whose lyrics express feelings without telling a continuous story, such as the Betawi song Cinta Manis. While lyrical folk songs are not truly tell the continued story. These types of songs are spiritual and other religious folk songs, folk songs that advise to do good, folk songs about courtship and marriage, songs whose lyrics are piled up, songs of babies and children, humorous songs, and regional singing and certain livelihoods. Folk songs that are narrative songs are folk songs that tell a story, which includes folk songs are ballads and epics.

Based on the usefulness, the folk songs can be divided into: 1) folk songs or cues that are used to arouse the spirit of "gotong royong" of the community, such as holopis kuntul baris from the East Java or rambate rata from South Sulawesi; 2) song of the game that used to accompany children playing in rows. For example, the singing baris terik tempe, ridong udele bodong (lined with vegetables from tempeh, Ridong the belly is prominent) from East Java.

Based on its contents, folk songs can be divided into three types, namely folk songs for children's, public, and spiritual games. Folk songs have the following functions: 1) solace, humorous singing, singing to accompany the game, and singing Nina Bobo; 2) spirit generation; 3) maintain local history and clarity: 4) social protest, regarding injustice in society, the state, and even the world.

\subsection{Tundang}

Popular song in West Kalimantan is Tundang. In folk songs, tundang are included in the types of spiritual folk songs because they are usually invited to contain messages or Islamic da'wah which is packaged in the form of rhyming pantun. Tundang initially meant that the pantun was drumming because the singer sang the pantun while drumming, but after the instruments (instruments) used increased and collaborated with the dance then Tundang changed the meaning to rhyming pantun. Tundang material is not only in the form of pantun, but also in the form of poetry, even though this art is still called Tundang because of the familiarity of the name in the community, until now 
this art is known as Tundang [11].

Tundang was first introduced in 1992 in Sanggau by Eddy Ibrahim. Tundang Art was born against the background of his desire to convey aspirations and ideas through a media, in addition to the media being able to convey ideas; it is hoped that it can also make people who hear them feel happy. To achieve this goal, Eddy, born in Pontianak on April 21, 1963, created Tundang as a place to channel his aspirations and ideas. The idea of Tundang has actually already been in his mind since the 1979 High School (SMA) but could not yet be realized, until at the sub-district Musabaqah Tilawah Quran (MTQ) performance in Sanggau in 1992, the art which was not yet named at the committee's request try to be displayed when the event void while waiting for the announcement of the winner of the race. Assisted by a loan drum from the Kasidah Group which also appeared on the show, Eddy began to dance while drumming. Because Eddy likes to dance, pantun he actually brought had been made before, even though he had not thought he would appear on the show beforehand. Eddy also spontaneously danced by taking the theme of funny events that happened at the location of the activity, thus making the audience laugh. The following is a snapshot of pantun he brought.

Buah mempelam buah kuini

(The fruit of these fruits)

Dipetik orang berjalan kaki

(Picked by people walking on foot)

Betapa gembira hati kita malam ini

(How happy are we tonight)

Bersama menyaksikan acara MTQ

(Together watch the MTQ)

Orang Berenang ke pulau sebelah

(People swim to the next island)

Di tengah laut ada buaya

(There is a crocodile in the middle of the sea)

Jika pemenang dapat hadiah

(If the winner gets a prize)

Janganlah lupa kepada saya

(Do not forget about me)

Pergi ke Kuala berjalan kaki

(Go to Kuala Lumpur walking on foot)

Dari Kuala kita ke Mempawah

(From Kuala we go to Mempawah)

Saya heran kalau ada acara MTQ

(I wonder if there is $M T Q$ )

Ngapai bah yang nonton saja orang yang tua-tua

(Why do we need to watch, it's for elderly)

Elok indah Sanggau Permai

(The beautiful side of Sanggau Permai)

Banyak orang pakai sepeda

(Many people use bicycles)

Kulah ronung penonton mulai nak ramai

(The audiences are very busy)

Lurah Beringin pun ikut main kasidah
(The Beringin headman is participated in the play)

Sungguh enak sekali rasanya lempar

(It's really good the taste of lempar)

Dimakan orang berlalap lobak

(Eaten by people along with turnips)

Saya lihat para dewan juri sangatlah lapar

(I see the juries are hungry)

Memborong bakso satu gerobak

(Buy once cart of meatballs)

Goreng pisang pakai mentega

(Fry bananas with butter)

Pisang raja di dalam peti

(Banana king in the box)

Yang menang janganlah bangga

(For the winner, do not proud)

Yang kalah jangan patah hati

(The loser do not hurt)

Kue lapes pakai durian

(Lapes cake use durian)

Panton abes cukup sekian

(Abes rhyme that is all)

The message in the art of Tundang delivered through poetry and pantun which is flexible, meaning that it is adapted to the theme or situation and conditions. Whether the message delivered or not depends on the method of delivery used. The method used must be in accordance with the condition of mad'u, so the process of delivering the message can run well. Submission of messages through Tundang art is done by the method of billisan (oral) and delivered directly with face to face between Tundang personnel and the audience. The advantage of the billisan method is being able to convey messages directly, quickly, and easily understood, because the characteristics are using language in the form of a series of words, and language is an effective communication tool because between dai and mad'u can understand messages quickly.

The rapid development of technology now makes communication facilities more sophisticated, now communication can be done via telephone, fax, radio, television, film, satellite, and etc. But still the most powerful means for human communication is face-to-face communication. If communication is done face-to-face to mad'u, then you can see and feel whether the "greeting is answered". For example, if Dai saw Mad'u nodding and his eyes closed, then he was not listening to the preaching delivered by Dai.

Likewise if you see mad'u whose eyes are staring but his vision is empty, he knows that mad'u is not listening and his mind is staring. There are also those who use the head when giving emphasis on the things we review and their eyes are glowing with signs that Mad'u is listening intently. All of these are characteristics of face-to-face communication that are not found in other forms of communication, such as communication through 
audio-visual media or print media.

There are a number of techniques used by Invite arts to convey da'wah messages. First, using poetry and pantun, both of them are oral traditions known in the field of literature. Literature is used in preaching because it has a distinctive beauty that can attract mad'u's interest, because someone in general has an instinct or a side of beauty. This statement was proven at the time of the Prophet Muhammad; literature was used as pleasure, love, and work in the life of the Arabians. Because of the love and pleasure of the Arabians for the extraordinary beauty of literature, Allah SWT revealed the Qur'an as one of the miracles to show the truth and greatness of the Divine in the most beautiful and most holy language as a "rival" of the oral culture that the Arabians are proud of at that time.

In the Malay literary tradition, the development of Islamic teachings in the form of poetry and poems can be seen through the works of Hamzah Fansuri who lived between the mid-16th century and the early 17 th century. Even in Aceh, the saga of sabil war becomes a monumental literary work in arousing the spirit of the jihad of the Acehnese against the Dutch. The story of the sabil war is able to "enchant" the Acehnese people to uphold the teachings of Islam with jihad fi sabilillah against the tyranny of the Netherlands [12].

Second, using several forms of language style, namely the style of language based on the choice of words, tones, and style of language based on the direct or indirect meaning. It is based on the choice of words using the language style of conversation, and the aim is to create a more intimate and relaxed atmosphere. To realize this goal, what must be considered is to choose the right words, do not let the words used make mad'u feel uncomfortable with the chant of Tundang poems. Therefore, it is necessary to select the words that are used, are appropriate or not with the audience. Considerations like this are done so that mad'u can understand the contents properly, without being forced, even to create an atmosphere of laughter and cheerfulness. Whether ethical considerations or words used must refer to the correct paradigm and foundation. In the Quran you can find good guidance, such as the terms qaulan ma'rufa (good and proper words), qaulan kariman (noble words), and qaulan maisura (words that are easy to understand).

The style of language based on the tone used is the medium style, which is the style of language directed at the effort to create an atmosphere of peace and pleasure, so that the tone is also soft, full of love, and healthy humor.

Third, one of the characteristics of Tundang Mayang Sanggar Pusaka art is humor, and every verse that is sung is inseparable from words or sentences that can make the audience laugh. The humor technique commonly used by Invite is a technique of superiority and degradation, which according to Rakhmat [13] is one technique that can make us laugh when we witness something that is strange, wrong or defective. Objects that make us laugh are odd, strange, and deviant objects. We laugh because we feel we don't have the "ridiculous" nature of the object. As subjects, we have advantages (superiority), while our laughing objects have low traits. When laughing always finds hidden intentions of humor conveyed.

Emphasis can be a powerful tool to attract the attention of the audience in listening to what the singer has to say. If the audience has listened to the chanting because of the emphasis, then it can be ascertained that the message delivered is easy to accept and will be longer in one's mind, because something followed enthusiastically will be more remembered. Repetition can also be jewelry or the beauty of poetry, with the similarity of sounds, words, and sentences making poetry more beautiful to enjoy and easier to understand. Fourth, based on the direct or indirect meaning, the style of language used is the style of rhetorical and figurative language. The style of rhetorical language is merely a deviation from ordinary construction to achieve a certain effect, while the style of figurative language is a further deviation, especially in the field of meaning. In Tundang art, the style of rhetorical language used consists of alliteration, assonance, rhyme, concurrency, enumeration, and parallelism. Meanwhile, the figurative language style used is a parable or comparison style (smile).

Parables usually equate one thing to another. What's interesting about this style is the style of parables, because with this style the message can be packaged with another atmosphere and more implicit, and through this style the chant will feel more beautiful.

\subsection{Local Wisdom Based Education}

Local wisdom-based education is education that is based more on enriching cultural values. This education teaches students to always be close to the concrete situations they face every day. In other words, this educational model invites all of us to always be close and maintain the surrounding situation that is of value in the local community. This education model can be identified by several things as follows:

\subsubsection{Protecting Ideas and Legal Basis}

The idea of local wisdom-based education originated from an expression "thinks globally acts locally" (thinking globally and acting locally). The purpose of the phrase is that one can take on any experience and knowledge, from any tribe and any nation, but in its application in an action when someone is in a place, then he must adjust to the values and culture in that place.

With the existence of global knowledge, one will easily be able to read and recognize a problem and solve it. Therefore someone needs to be knowledgeable so that the insight becomes relatively broad. But in terms of education in general and teaching and learning in particular, an educator is not enough just to be knowledgeable and 
broad-minded, but to reflect the transfer of knowlage (learning process) must also be accompanied by emotion skills namely how an educator must be able to enter the world where the students are located. In this problem there is one thing to remember that "a student who comes to a class in a school is not like a blank cup, but they have brought the knowledge and habits of the place where he lives". In other words, the environment that is the place of residence for one anal student is different from the environment in which the other students live. That way, of course, their social and economic status must be different. Likewise in local communities, it will certainly be different from other local communities. That is why in Indonesia there is a slogan "Bhineka Tunggal Ika" which means the slogan is that even though we come from different tribes and different cultures, we have one entity, namely Indonesia.

From the words of the slogan mentioned above, it can be concluded that the Indonesian state has indeed had many local people who certainly have different cultural diversity. So from that it is certain that the Indonesian state actually has a cultural wealth that certainly can give a color and pattern that can be developed into a national character. Education based on local wisdom is actually a form of reflection and realization of Government Regulation (PP) No. 19/2005 on National Education Standards, namely article 17 paragraph 1 which explains that "the curriculum level for elementary-high school education units, or other equivalent forms is developed in accordance with educational units, regional potential, socio-cultural, and students ".

\subsubsection{The Purpose and Benefits of Education Are Based on Local Wisdom}

The aim of local wisdom-based education is in accordance with the text set out in the national law, namely Law No. 20 of 2003 concerning the National Education System in Article 3, stating that national education functions to develop capabilities and shape national character and civilization who are dignified in order to educate the life of the nation. National education aims to develop the potential of students to become human beings who believe and fear God Almighty, have noble character, are healthy, knowledgeable, capable, creative, independent, and become democratic and responsible citizens. While the benefits of education based on local wisdom include:

a. Gives birth to generations that are competent and dignified

b. Reflect on cultural values

c. Participate in shaping the character of the nation

d. Contributing to the creation of a national identity

e. Take part in preserving national culture

\subsubsection{Value}

Speaking of values, of course it cannot be separated from a word of integrity, which if discussed further, and then the integrity will become an identity. In this case, there is a study conducted at Harvard University in the United States (Ali Ibrahim Akbar, 2000), which states that one's success cannot be determined solely due to the influence of knowledge and technical abilities (hard skills), but more because of the ability to manage themselves and others (soft skills). This study revealed that success is only determined by about 20 percent by hard skills and the remaining 80 percent is more determined by soft skills.

The value of integrity will be an identity in a nation. With this value, a nation will become advanced and dignified. This also happened in the world of education. A teacher can never be separated from a simple word called value, because with this value, a teacher will have an integrity which will eventually become an identity, and with that identity, a teacher will have a distinctiveness that will differentiate him/her from other teachers. This is where there is usually a tendency that is common among instructors; they often compete with the teaching methods they have and have learned. They are not aware that integrity cannot be simplified by just a method word. In other words, it can be said as well as any method, if without the integrity that is in the instructor, the method will not be effective.

The way that can be done by an education practitioner, whether it is a teacher or a student, is to explore the potential values that exist in a local community. From there, an education actor will be able to make changes in the world of education that he lived and practiced. This is in accordance with a term derived from one of the intellectuals from Morocco, namely the late Muhammad Abed Al-Jabiri who said "Attajdidu mina dhdhahl" change must depart from our tradition, meaning that change is not by borrowing the traditions of other people or nations.

In light of introduction of environmental identity through learning media, the method that can be used for the introduction of the environment in learning based on local wisdom is actually very varied. For middle-high school students and Indonesian language teachers, English and Javanese languages can assign students to make essays about the city's tourism potential. For art teachers, you can teach how to draw srotongan house, limasan and typical Javanese joglo. For mathematics teachers, you can introduce geometric shapes to students through the form of traditional house roofs. Another method that can be practiced is through storytelling by pictures, photos, puppets, musical accompaniment, miniatures of traditional houses, or interesting teacher luggage. This kind of method is very effective in educating students at the Play Group, Kindergarten and Elementary School levels.

\subsubsection{Words of Wisdom that Contain Motivation in Local Languages (Javanese)}

A locality usually has a lot of cultural wealth that is unique and contains high values. Some of them are a few words of wisdom / words of wisdom that are often used as 
slogans in the activities of the daily (Javanese) community:

a. Rame ing Gawe Sepi ing Pamrih: This sentence has a meaning that contains a command or invitation. That is an invitation for someone to always do good to anyone, without favoritism. After doing well, someone is invited not to expect anything in return for what he has done. From the expression of the word, you can imagine what will happen in Java especially if most of the people can interpret and apply these expressions in daily life? The next question is what will happen in the country of Indonesia, if all leaders and officials from the Javanese tribe can interpret and apply it in their government activities? From this phrase, it can now be seen that the actual value of a local culture is something great.

b. Ing Ngarsa Sung Tulada, ing Madya Mangun Karsa, Tutwuri Handayani: this sentence is an invitation for someone to be prepared for their conditions and position. If he becomes a leader then he is able to be a good role model; if he is positioned to become a mobilizer (minister / high official) then he is able to maintain the quality of his performance, and if he becomes an official / employee / command officer and so on, he is able to maintain dedication (giving strength / support).

c. Becik Ketit Ala Ketara: This sentence inspires anyone, that in the end someone will reap what he has planted. In that way there is no reason for someone to do a bad deed, because in the end it is certain that the person will not be able to get happiness.

Based on the three phrases above, it's enough to make some how noble the potential value that contained in local Indonesian society. The illustrations above are just a little sample that taken from one of the local community that existed in Indonesia namely Java, and many more other tribes that existed in Indonesia, where every local has its own characteristics. Like the Batak tribe which is thick with its openness, Java is almost identical to its subtlety, and the Madurese tribe who uphold the values of self-esteem. So now the question is what if every value that is typical in each local community is protected and maintained, developed and applied in every aspect of life. After it is integrated and so that it forms a unity, namely Indonesia, it will certainly be great, right?

\section{Conclusions}

Tundang, as one of the oral folklore in folk songs, can be used for learning in schools with cooperation between the teachers and the students. The preservation of the songs of the people of West Kalimantan can make changes to the preservation of other cultures by elevating them to a performance art that can be developed, namely increasing their coaching and expanding the area of its spread. Based on the phenomenon that occurs in Indonesia today, of course if all the citizens from all layers in Indonesia felt concerned and sad. Similar to the world of education, it's time to be the front guard in the mission of creating a large and characterized Indonesian.

In Malay tundang, there are cultural values and education for students/listeners/audiences. There are suggestions and good advice for character building. Therefore, the internalization of cultural values and characters in Malay tundang is very good for learners. Participants can learn and interact regarding to Malay knowledge and philosophy contained in tundang speech. Students can learn better about soft skill knowledge through Malay tundang to have good character and cognitive about nature, social, culture, religion, education, and the latest beneficial issues that can be known by learners

\section{Acknowledgement}

The researcher thanked LPDP BUDI DN as the research sponsor. Further thanks go to Rector of IKIP PGRI Pontianak, west Borneo who has given the permission for doctoral study. Thanks to the promoter, co-promoter 1, and co-promoter 2 who have guided in carrying out the research. The researcher also expressed his gratitude to the Tundang Mayang Pusaka studio led by Eddy Ibrahim in Mempawah west Borneo for giving permission in conducting the research

\section{REFERENCES}

[1] Atran, S.: 'In gods we trust: The evolutionary landscape of religion' (Oxford University Press, 2004. 2004)

[2] Geertz, C., and Banton, M.: 'Religion as a cultural system', 1966

[3] Geertz, C.: 'The interpretation of cultures' (Basic books, 1973. 1973)

[4] Chandarlapaty, R.: 'Re-creating Paul Bowles, the Other, and the Imagination: Music, Film, and Photography' (Lexington Books, 2014. 2014)

[5] Bronner, S.J.: 'The meaning of folklore', The analytical essays of Alan Dundes, 2007

[6] Endraswara, S.: 'Folklor Jawa: Macam, Bentuk, dan Nilainya', Jakarta: Penaku, 2010

[7] Danandjaja, J.: 'Folklor Indonesia: ilmu gosip, dongeng dan lain-lain' (Grafiti Pers, 1984. 1984)

[8] Soeryawan, R.D.: 'Pengetahuan dasar tentang kebudayaan Sunda' (Dikeluarkan oleh Lembaga Kebudayaan, Universitas Pasundan, 1984. 1984)

[9] Rusyana, Y.: 'Memperlakukan Sastra Berbahasa Indonesia dan Sastra Berbahasa Daerah Sebagai Sastra Milik 
Nasional', Makalah Pertemuan Ilmiah Nasional HISKI, 2000

[10] Said, A.: 'Nyanyian Rakyat: Khazanah bangsa yang hilang.' (Kementerian Kebudayaan, Kesenian dan Warisan Malaysia., 2004. 2004)

[11] Ibrahim, I.: 'contiguity of islam and local tradition on the hinterland malays of west kalimantan', Ulumuna, 2018, pp. $\mathrm{xxx}-\mathrm{xxx}$

[12] Ibrahim, A.A.: 'Pendidikan Karakter', in Editor (Ed.)^(Eds.): 'Book Pendidikan Karakter' (USA: Harvard University, 2000, edn.), pp.

[13] Rakhmat, J.: 'Psikologi Komunikasi, edisi revisi. 2007 ' (Remaja Rosdakarya 2007. 2007) 